\title{
Investigation of the Voltammetric Behavior of Methyldopa at a Poly ( $p$-Aminobenzene Sulfonic Acid) Modified Sensor
}

\section{Poli ( $p$-Aminobenzen Sülfonik Asit) Modifiye Sensör ile Metildopanın Voltametrik Davranışının İncelenmesi}

\author{
(D) Gamze ERDOĞDU1*, (D) Şevket Zişan YAĞCI1, (D) Ebru KUYUMCU SAVAN2 \\ 1'nönü University, Faculty of Arts and Sciences, Department of Chemistry, Malatya, Turkey \\ 2Inönü University, Faculty of Pharmacy, Department of Basic Pharmaceutical Sciences, Division of Analytical Chemistry, Malatya, Turkey
}

\begin{abstract}
Objectives: The aim was to modify carbon electrodes with ( $p$-aminobenzene sulfonic acid) and use them as a sensor for sensitive and reliable detection of methyldopa (MD) and ascorbic acid.

Materials and Methods: Electropolymerization was performed by cyclic voltammetry in $0.1 \mathrm{M} \mathrm{KCl}$ solution. The modified sensor has a high electrocatalytic effect for oxidation of MD, which appeared in the $\mathrm{pH}$ range of 2-11 by differential pulse voltammetry (DPV) techniques.

Results: For the voltammetric determination of MD, the best results were acquired by DPV in phosphate buffer solution (PBS) (pH 3). The calibration plot of the proposed sensor is linear in two concentration ranges of 1.0-30 and 30.0-300.0 $\mu \mathrm{M}$. The calibration equations over these ranges are $I_{p a}(\mu \mathrm{A})=1.21 \times C(\mu \mathrm{M})+30.81, \mathrm{R}^{2}=0.994$ and $I_{p a}(\mu \mathrm{A})=0.53 \times C(\mu \mathrm{M})+53.30, R^{2}=0.9975$, respectively. In the sensitivity studies, the limit of quantification and the limit of detection were $10.6 \mathrm{nM}$ and $5.0 \mathrm{nM}$, respectively. The modified sensor was used for the simultaneous determination of interfering substances such as MD and ascorbic acid in real samples.

Conclusion: The obtained results revealed that the prepared modified electrode and the proposed method have good sensitivity, repeatability, reproducibility, and stability.
\end{abstract}

Key words: Methyldopa, voltammetry, poly ( $p$-aminobenzene sulfonic acid), ascorbic acid, glassy carbon electrode

Öz

Amaç: Karbon elektrotların poli ( $p$-aminobenzen sülfonik asit) ile modifikasyonu ve metildopa (MD) ve askorbik asitin hassas ve güvenilir bir şekilde tayini için bir sensör olarak kullanılması.

Gereç ve Yöntemler: Elektropolimerizasyon, $0.1 \mathrm{M} \mathrm{KCl}$ çözeltisi içerisinde dönüşümlü voltametri (CV) ile gerçekleştirildi. Modifiye edilmiş sensör metildopanın oksidasyonu için yüksek elektrokatalitik etkiye sahiptir, bu da 2-12 pH aralığında diferansiyel puls voltametri tekniği ile gözlenmiștir.

Bulgular: MD'nin voltametrik tayini için, en iyi sonuçlar fosfat tampon çözeltisinde (PBS) (pH 3) DPV tekniği ile elde edildi. Bu aralıklarda kalibrasyon denklemi sırasıyla: $I_{p a}(\mu \mathrm{A})=1,21 \times C(\mu \mathrm{M})+30,81, R^{2}=0,994$ ve $I_{p a}(\mu \mathrm{A})=0,53 \times C(\mu \mathrm{M})+53,30, R^{2}=0,9975$. Duyarlılık çalışmalarında, kantitatif tayin sınırı (LOQ) ve en küçük tayin sınırı sırasıyla $10,6 \mathrm{nM}$ ve $5,0 \mathrm{nM}$ 'diır. Duyarlılık çalışmalarında, tayin alt sınırı ve tayin sınırı sırasıyla $10.6 \mathrm{nM}$ ve $5.0 \mathrm{nM}$ idi. Modifiye edilmiş sensör, MD ile askorbik asit gibi girişim yapan maddelerin gerçek örneklerde eş zamanlı tayini için kullanıldı.

Sonuç: Elde edilen sonuçlar, modifiye edilmiş elektrot ve önerilen yöntemin iyi duyarlılık, tekrarlanabilirlik, tekrar üretilebilirlik ve kararlılı̆̆a sahip olduğunu ortaya çıkardı.

Anahtar kelimeler: Metildopa, voltametri, poli ( $p$-amino benzen sülfonik asit), askorbik asit, camsı karbon elektrot 


\section{INTRODUCTION}

Methyldopa (MD) is a catecholamine that is known by its chemical name 2-methyl-3-(3,4-dihydroxyphenyl)-DL-alanine (Figure 1), and it is widely used to lower blood pressure. MD is a centrally acting adrenal receptor that reduces high blood pressure and sympathetic tone. In adrenergic nerve terminals, it is converted to $\alpha$-methyl noradrenaline, and its antihypertensive effect seems to be due to this agent stimulating the central adrenoreceptors. $^{2}$

Various methods like high-performance liquid chromatography with ultraviolet (UV) detection, ${ }^{3}$ polarography, ${ }^{4}$ potentiometry, ${ }^{5}$ UV visible spectrophotometry, ${ }^{6}$ and flow injection techniques ${ }^{7,8}$ were reported previously for the determination of MD. However, many of these techniques require expensive equipment and are time consuming. In addition, since these catecholamines are electrochemically active, it is also possible to determine the nature of the molecules that provide neurotransmission by electrochemical methods. Therefore, it is important to detect MD in the presence of ascorbic acid (AA) by a reliable method that has good selectivity and sensitivity.

AA (vitamin $C$ ) is a biologically and industrially important substance. ${ }^{9}$ The coexistence of $A A, M D$, and other catecholamines with very similar oxidation potentials leads to the response obtained by electrochemical techniques. For this reason, the increased sensitivity and selectivity of the new sensors produced to the MD has long been the subject of research. Using polymer modified electrodes solves this problem. The electrochemical behavior of MD was studied at various polymer electrodes. ${ }^{10-17}$

However, some disadvantages exist in the previously reported modified electrodes. AA exists as an anion in physiological $\mathrm{pH}$ (7.4), whereas MD exists as a cation. There are high electron density sulfo groups and electron-rich $\mathrm{N}$ atoms in the structure of $p$-aminobenzene sulfonic acid (ABSA). For this reason, a negatively charged polymer film is required to eliminate the interference of $A A$ in the determination of MD. The $p$-ABSA molecule has high electron density sulfo groups and $p$-ABSA films are negatively charged. Due to the electrostatic repulsion between the negatively charged sulfo groups and the AA anions in the modified sensor, the AA shifts to a more negative potential and the dopaminic acid can be easily separated from it. The $p$-ABSA modified sensor can show high selectivity against MD. ${ }^{18}$

In the present study, electroanalytical methods were developed to detect MD in drug samples rapidly, reliably, and sensitively using an electrode modified with poly ( $p$-ABSA). It has been

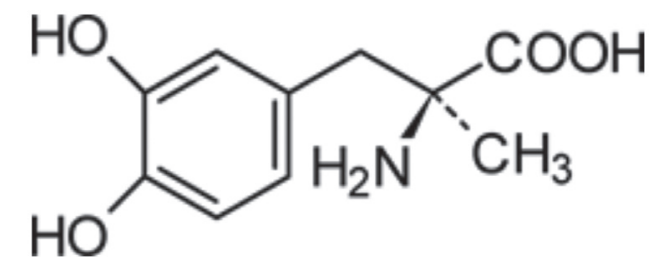

Figure 1. Molecular structure of methyldopa determined that the modified sensor can be utilized for MD determination even in the presence of $A A$ at the same time. Another significant advantage of these techniques over other ones is that they can be applied directly to the analysis of pharmaceutical dosage forms and biological samples without the need for extensive sample preparation, as there is no interaction between the adjuvants and the endogenous substances.

The analytical determination parameters such as the limit of detection (LOD), the limit of quantification ( $L O Q$ ), and the concentration range were determined, and the amount of MD in the drug tablets and blood serum was found. To test the accuracy of the applied voltammetric method, MD recovery studies were performed in real samples.

\section{MATERIALS AND METHODS}

\section{Materials}

Alfamet tablets containing $250 \mathrm{mg}$ of MD were kindly supplied by I.E. Ulagay (Turkey). All chemicals were of analytical purity and were procured from Merck (Darmstadt, Germany) or Sigma Chemical Company. Prior to the polymerization the solutions of monomer were held in nitrogen gas atmosphere for about 10 min, and during the electropolymerization the electrochemical cell was covered with nitrogen gas. Voltammetric experiments were carried out in phosphate buffer solution ( $\mathrm{pH}$ 3.0). MD and AA solutions were freshly prepared before the experiments. All solutions were prepared with ultrapure water.

\section{Instrumentation}

In the voltammetry experiments, a BAS (Bioanalytical Systems, Inc.) 100BW electrochemical analyzer was used. This analyzer is connected to a personal computer and the device is controlled and data stored and processed by means of software loaded and running under MS Windows. An electrode system consisting of a $\mathrm{Ag} / \mathrm{AgCl}$ reference electrode $(\mathrm{CHI})$, a glassy carbon disc working electrode (geometric area: $6.85 \mathrm{~mm}^{2}, \mathrm{CHI}$ ) and a $\mathrm{Pt}$ wire coil as auxiliary electrode $(\mathrm{CHI})$ was used.

\section{Modification of poly ( $p$-ABSA) sensor}

Before modification, the working glassy carbon electrode (GCE) was cleaned using 0.3 and $0.05 \mu \mathrm{m} \mathrm{Al}_{2} \mathrm{O}_{3}$ slurry on polishing materials. Then the polished GCE was sonicated in 1:1 nitric acid solution for $10 \mathrm{~min}$ and washed with ultrapure water. Afterwards, the GCE was electrochemically cleaned by cycling 20 times in the potential range of -0.7 to $1.7 \mathrm{~V}$ with a scan rate of $100 \mathrm{mV} / \mathrm{s}$ in $0.5 \mathrm{M} \mathrm{H}_{2} \mathrm{SO}_{4}$. After that, the electrode was plunged into $0.1 \mathrm{M} \mathrm{KCl}$ solution containing $5.0 \mathrm{mM} \mathrm{p}$-ABSA and the modification procedure was performed by cyclic sweeping from -1.5 to $2.5 \mathrm{~V}$ for 14 cycles at $50 \mathrm{mV} / \mathrm{s}$. Then the modified sensor was conditioned by cyclic voltammetry in the potential range of -0.5 to $0.5 \mathrm{~V}$ with $100 \mathrm{mV} / \mathrm{s}$ in $\mathrm{pH} 3.0$ phosphate buffer solution (PBS) and was stored in PBS ( $\mathrm{pH} 3.0$ ).

\section{Preparation of real samples}

Tablets of MD with the commercial name Alfamet were prepared. Each tablet contains $250 \mathrm{mg}$ of MD. Five MD tablets were finely 
powdered using a mortar and pestle and then an appropriate amount of this sample containing a known amount of the active material was weighed and dissolved with double distilled water. The prepared mixture was filtered using filter paper and diluted to appropriate amounts with double distilled water. The serum samples were collected from a research hospital and were sonicated (15 min with $5000 \mathrm{rpm}$ ) and then diluted 10 times with double distilled water without any additional pretreatment. Before voltammetric determination, appropriate amounts of the prepared real samples were added to $10 \mathrm{~mL}$ of phosphate buffer solution with optimum $\mathrm{pH}(\mathrm{pH} 3.0)$, followed by transfer to the electrochemical cell for electrochemical measurements. The standard addition method was used to determine MD in the real and spiked samples.

\section{RESULTS}

\section{Electropolymerization of $p$-aminobenzene sulfonic acid}

Figure 2 shows the electropolymerization of $p$-ABSA at the GCE surface. The electropolymerization was performed in 0.1 $\mathrm{M} \mathrm{KCl}$ solution containing $5.0 \mathrm{mM} p$-ABSA at a GCE by cyclic voltammetry in the potential range of -1.5 to $2.5 \mathrm{~V}$. In the first cycle, two reduction peaks were obtained at $0.452 \mathrm{~V}$ (peak $\mathrm{A}$ ) and $0.449 \mathrm{~V}$ (peak $\mathrm{B}$ ), which might be related to the reduction of $p$-ABSA. Again, in the first cycle, an oxidation peak was observed at $0.824 \mathrm{~V}$ (peak $\mathrm{C}$ ). In the next and subsequent cycles, following the continuous scan, broader peaks were monitored, indicating that the polymer film was constantly growing. It could be observed that film growth was faster for the first five cycles than for the other cycles and also the next cycles no longer existed. These findings show that $p$-ABSA was coated on the GCE surface by electrodeposition. A brown polymer was formed that was properly bonded on the GCE surface.

\section{The effect of film thickness on MD response}

The film thickness, which is determined by the number of cycles of electropolymerization, is one of the most important factors

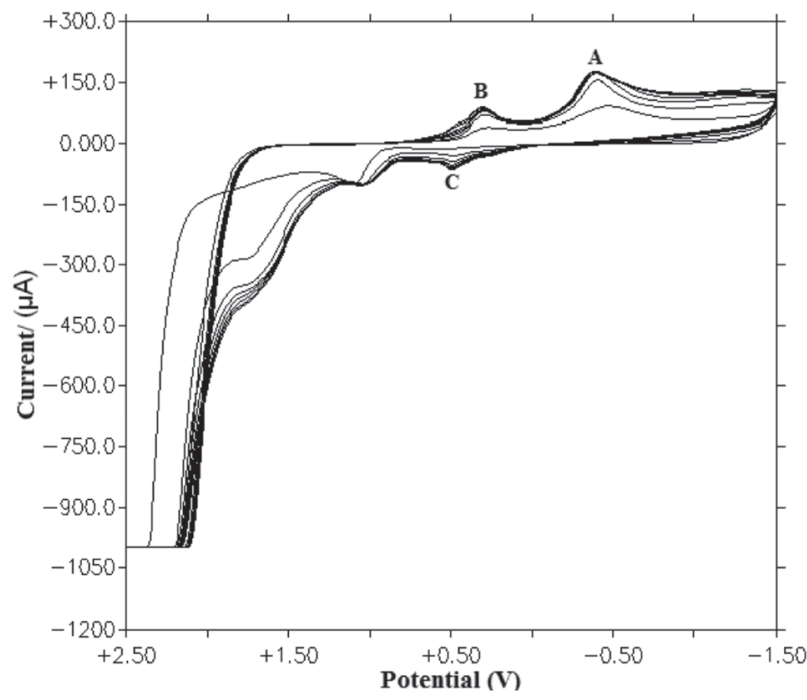

Figure 2. Cyclic voltammetries of $5 \mathrm{mM}$-aminobenzene sulfonic acid in $0.1 \mathrm{M} \mathrm{KCl}$ at glassy carbon electrode, scan rate: $50 \mathrm{mV} / \mathrm{s}, 14$ cycles determining the polymer film selectivity property. By altering the amount of charge consumed during electropolymerization, it is possible to obtain poly ( $p$-ABSA) films at desired thicknesses. Different film thicknesses were obtained by varying the cycles of the cyclic voltammetry. The selectivity of poly ( $p$-ABSA) sensors prepared in the range of 8-18 cycles to $M D$ and $A A$ was systematically examined. From the DPV results of MD, it was observed that regular and repetitive responses could be obtained at 14 cycle film thickness. This can be seen from Figure 3. Furthermore, the effect of the number of cycles on the electropolymerization was calculated as $64.42 \%$. This value was calculated from the ratio of the highest peak current to the peak current of the first polymer film.

\section{Electrochemical behavior of MD at poly ( $p$-ABSA) modified sensor}

The voltammograms achieved by cyclic voltammetry of MD show a reduction wave at a potential of nearly $200 \mathrm{mV}$ and an oxidation peak of nearly $220 \mathrm{mV}$ (Figure 4). The electrochemical oxidation of MD was studied by cyclic voltammetry at the surface of the bare and poly ( $p$-ABSA) modified GCE. The oxidation of MD shows a weak peak on the bare $G C$ at nearly $0.590 \mathrm{~V}$ but the experimental results for the modified GCE show a well-defined anodic peak at the peak potential of $0.220 \mathrm{~V}$ with respect to the $\mathrm{Ag} / \mathrm{AgCl}$ reference electrode. The peak current and peak potential values recorded at the GCE electrode were $0.61 \mu \mathrm{A}$ and $0.590 \mathrm{mV}$, respectively. However, at the poly ( $p$-ABSA) electrode these values were observed to be 30.48 $\mu \mathrm{A}$ and $0.220 \mathrm{mV}$, respectively (Figure 4). Consequently, in comparison with the data recorded from the bare GCE electrode, an increase in peak current and a decrease in overpotential of MD were obtained at the modified GC electrode. Therefore, it was assessed as an electrocatalytic effect for the oxidation of MD on the modified surface. It could be observed that the oxidation peak current for the modified electrode significantly increased and it was almost 50 times higher than that for the unmodified electrode. This behavior is due to adsorption of

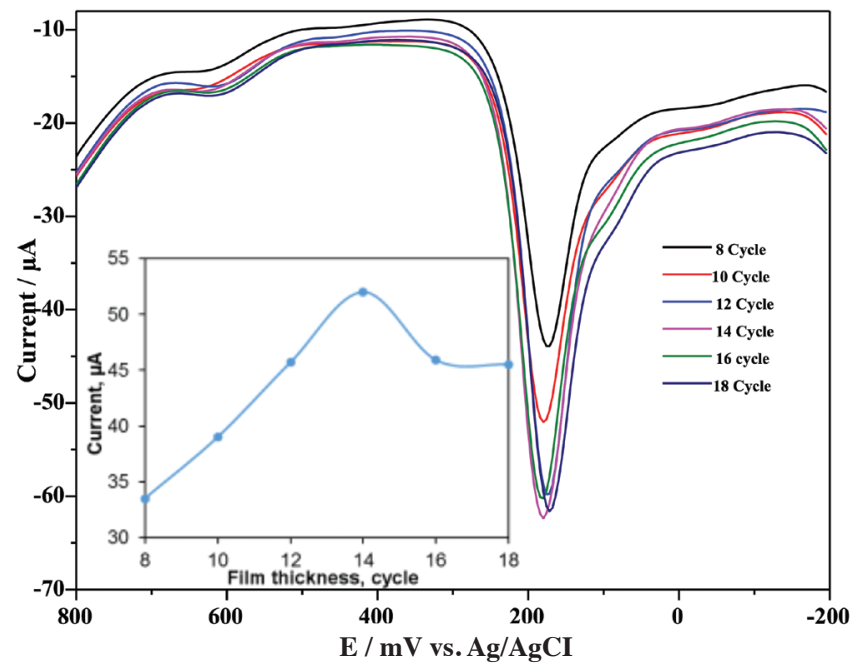

Figure 3. Differential pulse voltammetries of increasing film thicknesses of $0.01 \mathrm{mM}$ methyldopa (MD) in $0.1 \mathrm{M}$ phosphate buffer solution ( $\mathrm{pH}$ 3.0) at poly ( $p$-aminobenzene sulfonic acid) modified sensor. The relationship between film thickness and the peak current of MD (inset) 
MD on the surface of $p$-ABSA by interaction of MD functional groups such as $\mathrm{NH}_{2}, \mathrm{COOH}$, and $\mathrm{OH}$ with carboxyl groups of activated $p$-ABSA on the surface of the electrode. Thus sensitivity was significantly enhanced due to preconcentration of MD on the active surface of $p$-ABSA. Moreover, as shown in Figure $4 \mathrm{~B}$, the onset potential for $M D$ oxidation at the poly ( $p$-ABSA) electrode is lower than its oxidation at the bare GCE (Figure 4B) because of the catalytic behavior of the modified electrode. However, the potential peak at the bare GCE (0.59 V) is higher than the potential peak at the modified GCE $(0.220 \mathrm{~V})$. The effect of scan rate on the oxidation peak current of 0.01 $\mathrm{mM}$ MD was studied. With the scan rate increasing, the anodic peak current increased. A good linearity between the square root of scan rate and peak current was obtained in the range of $10-250 \mathrm{mV} \mathrm{s}^{-1}$. The linear regression equation was $I_{\mathrm{p}}(\mu \mathrm{A})=$ $0.502 v^{1 / 2}-0.899$ with correlation coefficient $R^{2}=0.998$. The correlation coefficient is very close to 1.0 , showing that the oxidation process is diffusion controlled. Furthermore, the plot of the logarithm of peak current versus logarithm scan rate has a slope of 0.63 , which is almost the theoretical value of 0.56 . The equation was $\log l_{p}(\mu \mathrm{A})=0.63 \log v-0.7041\left(R^{2}=0.998\right)$ on the modified electrode. This indicates a diffusion controlled electron process of MD oxidation at the poly ( $p$-ABSA) modified GCE.

\section{DISCUSSION}

The electrostatic interaction between the modified GCE electrode and MD contributed to the enhancement of sensitivity and electroactivity. The oxidation peak of $\mathrm{MD}$ at $\mathrm{pH} 3.0$ is irreversible and thus with an increase in peak height the peak potential shifts to lower potential. However, onset potential, which shows the kinetic of the reaction, decreased for the modified GCE compared to the bare GCE and thus sensitivity and selectivity increased because of these effects.

\section{Electrolyte type effect on voltammetric behavior of $M D$}

By selecting an appropriate supporting electrolyte solution, a

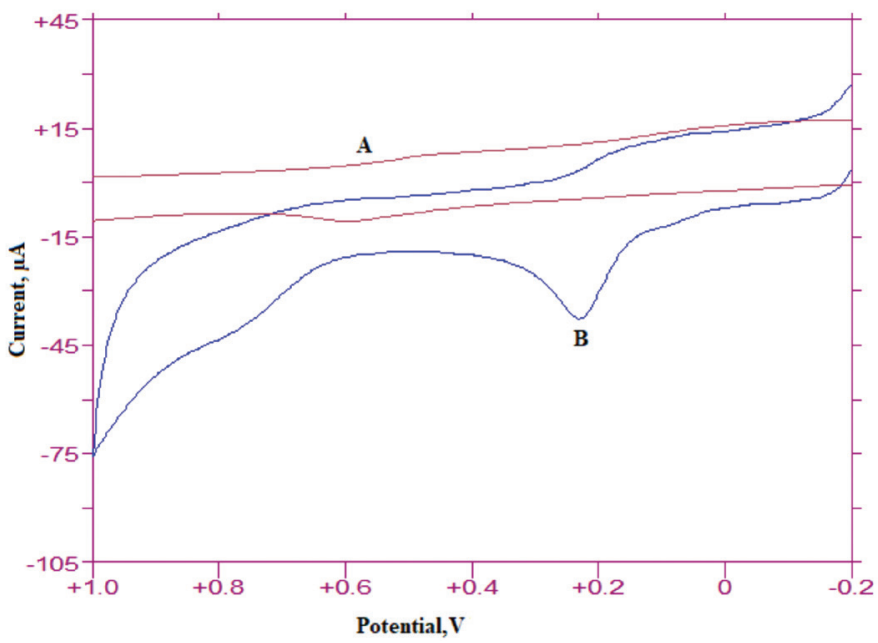

Figure 4. Cyclic voltammetries of $0.01 \mathrm{mM}$ methyldopa in $0.1 \mathrm{mM}$ phosphate buffer solution ( $\mathrm{pH}$ 3.0) (A) glassy carbon electrode, (B) at poly ( $p$-aminobenzene sulfonic acid) modified sensor. Scan rate: $50 \mathrm{mV} / \mathrm{s}$ conductive environment is created between the submerged electrodes.

The choice of supporting electrolyte depends on MD's resolution, dissociation degree, and nucleophilic character. For this purpose, voltammograms of $\mathrm{MD}$ in $\mathrm{Na}_{2} \mathrm{SO}_{4}, \mathrm{PBS}(\mathrm{pH}$ 7.0), $\mathrm{NaNO}_{3}, \mathrm{NaClO}_{4}, \mathrm{NaCl}$, and $\mathrm{KCl}$ supporting electrolytes (electrolytes concentration, $0.1 \mathrm{M}$ ) were recorded (Figure 5). While a voltammogram was taken at $\mathrm{pH} 7.0$ for PBS, voltammograms were taken at the native $\mathrm{pH}$ of the other electrolyte species.

\section{Effect of $\mathrm{pH}$ on the peak potential and peak current of $M D$}

The peak current and potential are dependent on the $\mathrm{pH}$ of the solution. To find the optimum $\mathrm{pH}$, the influence of $\mathrm{pH}$ over the range of 2.0-11.0 on the performance of the sensor was investigated. Experimental results for MD are shown in Figure 6. It was found that the anodic peak current of MD increased with increment of acidity, and reached its maximum value at $\mathrm{pH}$ 3.0. Therefore, $\mathrm{pH} 3.0$ was selected as the optimum $\mathrm{pH}$ for the determination of MD. Increasing peak current with the increase in acidity showed that the mechanism for oxidation of MD was a proton dependent reaction.

It was observed that as the $\mathrm{pH}$ of solution was increased, the oxidation peak potential shifted to negative potential values. The negative shift and the peak potential showed a linear relationship with a slope of $-52.4 \mathrm{mV} / \mathrm{pH}$ in the $\mathrm{pH}$ range of 2.0-5.0. This slope approximately revealed that the number of protons in the process was equal with the number of electrons transferred in the oxidation reaction of MD.

\section{Determination of $M D$ in the presence of $A A$}

Determination of MD in poly ( $p$-ABSA) was done with differential pulse voltammetry. Differential pulse voltammograms of different concentrations of MD on the poly ( $p$-ABSA) modified GCE are shown in Figure 7. The data of the obtained calibration charts are shown in Table 1. The calibration plot of the proposed sensor is linear in two concentration ranges of 1.0-30.0 and 30.0-300.0 $\mu \mathrm{M}$.

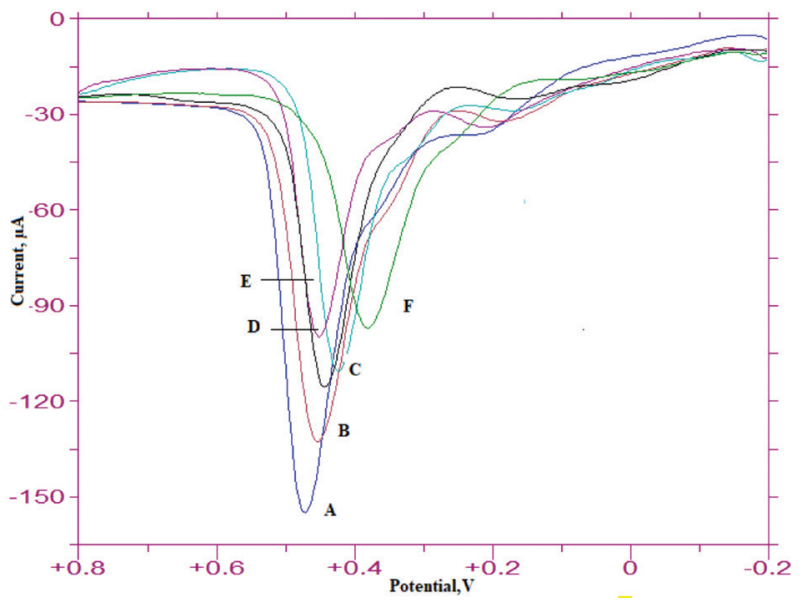

Figure 5. Electrolyte effect on voltammetric analysis of $0.01 \mathrm{mM}$ methyldopa at poly ( $p$-aminobenzene sulfonic acid) sensor. A) Phosphate buffer solution ( $\mathrm{pH}$ 7.0), B) $\mathrm{NaClO}_{4}$, C) $\mathrm{KCl}$, D) $\left.\mathrm{NaCl}, \mathrm{E}\right) \mathrm{NaNO}_{3}$, and F) $\mathrm{Na}_{2} \mathrm{SO}_{4}$. Electrolyte concentration was $0.1 \mathrm{M}$ 


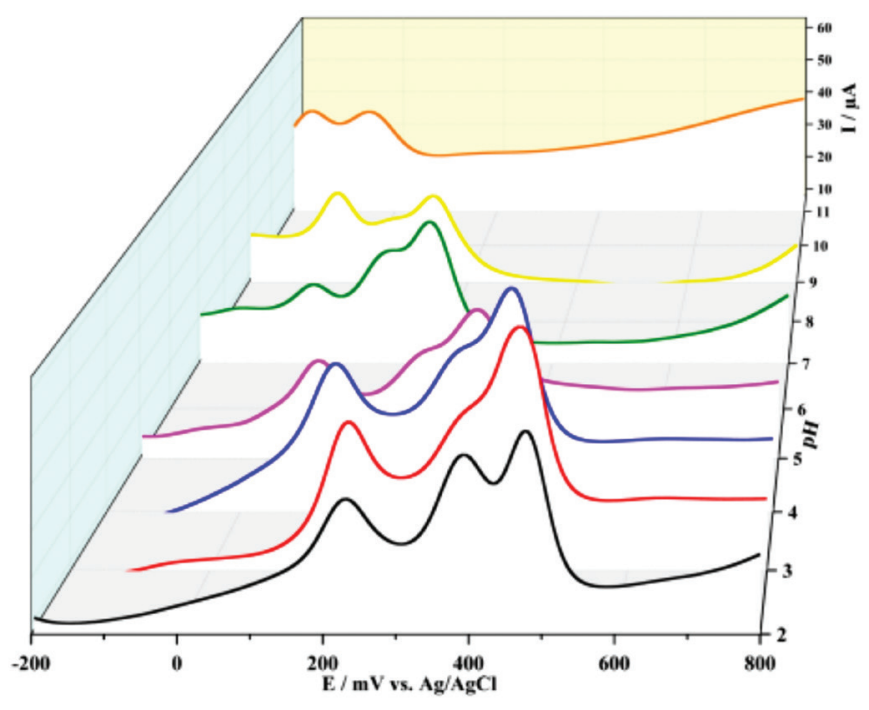

Figure 6. Differential pulse voltammetry responses of $0.01 \mathrm{mM}$ methyldopa and $1.0 \mathrm{mM} \mathrm{AA}$ at modified sensor in phosphate buffer solution medium at different pHs: 2.0, 3.0, 4.0, 5.0, 7.0, 9.0, 11.0. Scan rate, $50 \mathrm{mV} / \mathrm{s}$

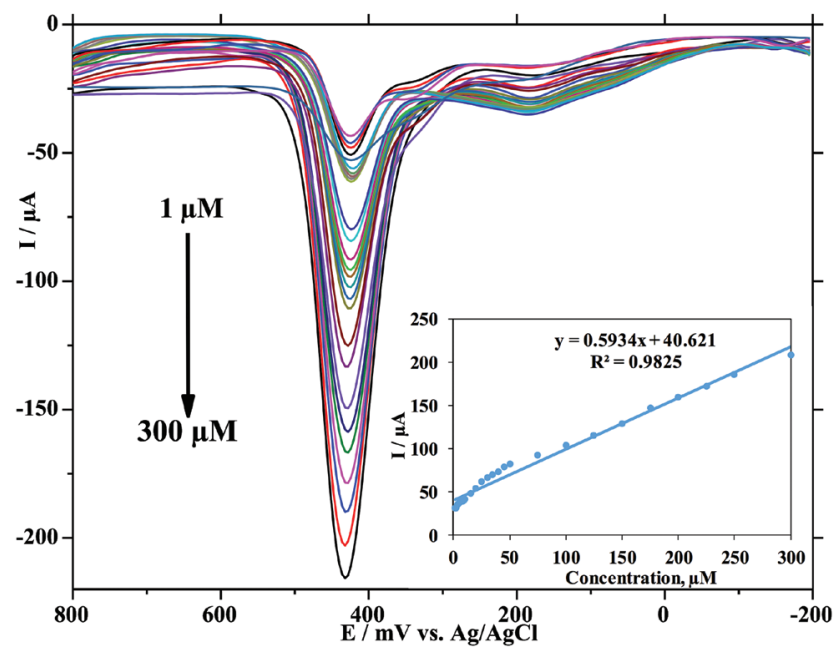

Figure 7. Differential pulse voltammograms and calibration graphs in increasing concentration of methyldopa in $0.1 \mathrm{M}$ phosphate buffer solution ( $\mathrm{pH}$ 3.0) at poly ( $p$-aminobenzene sulfonic acid) modified sensor. The calibration chart of 1.0-300.0 $\mu \mathrm{M}$ methyldopa (inset)

\section{Table 1. The data of calibration charts}

Linear concentration range $(\mu \mathrm{M})$

\begin{tabular}{lll}
\hline Parameters & $1.0-30.0$ & $30.0-300.0$ \\
\hline Correlation coefficient & 0.9944 & 0.9975 \\
\hline Standard error of slope & 0.0263 & 0.0075 \\
\hline Standard error of intercept & 0.3538 & 1.167
\end{tabular}

The calibration equations over theses ranges are $I_{p a}(\mu \mathrm{A})=1.21 \times C \quad(\mu \mathrm{M})+30.81, R^{2}=0.9944$, and $I_{p a}(\mu \mathrm{A})=0.53 \mathrm{C}$ $(\mu \mathrm{M})+53.30, R^{2}=0.9975$, respectively. $\mathrm{LOD}$ and $\mathrm{LOQ}$ were calculated as $5.0 \mathrm{nM}$ and $10.6 \mathrm{nM}(S / N=3)$, respectively. The relative standard deviation (RSD) for $M D$ and 5 repeated measurements was less than $3 \%$.

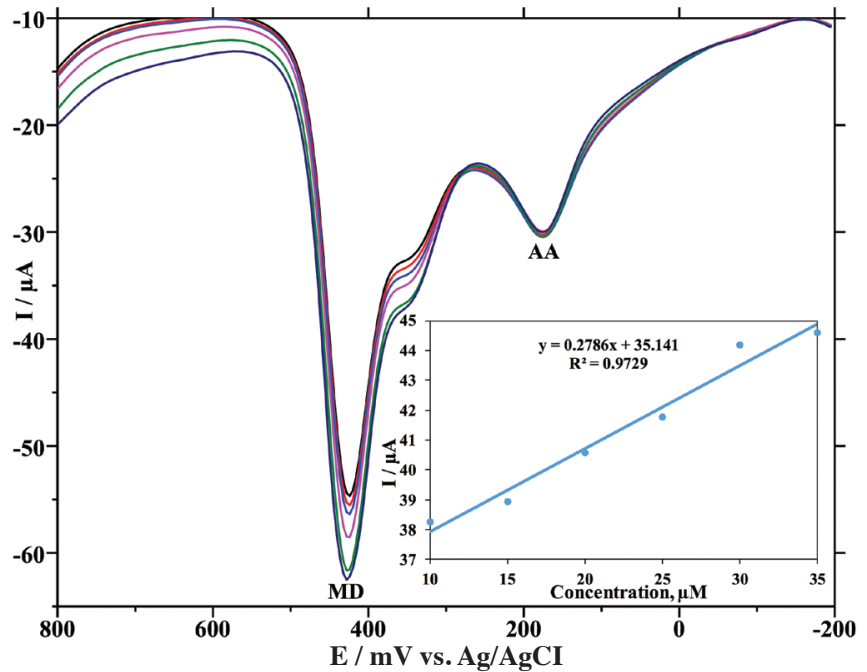

Figure 8 . The increasing concentration of methyldopa $(0.01,0.015,0.020$, $0.025,0.030,0.035 \mathrm{mM}$ ) with $0.5 \mathrm{mM}$ ascorbic acid at poly ( $p$-aminobenzene sulfonic acid) modified sensor in $0.1 \mathrm{M}$ phosphate buffer solution ( $\mathrm{pH} 3.0$ )

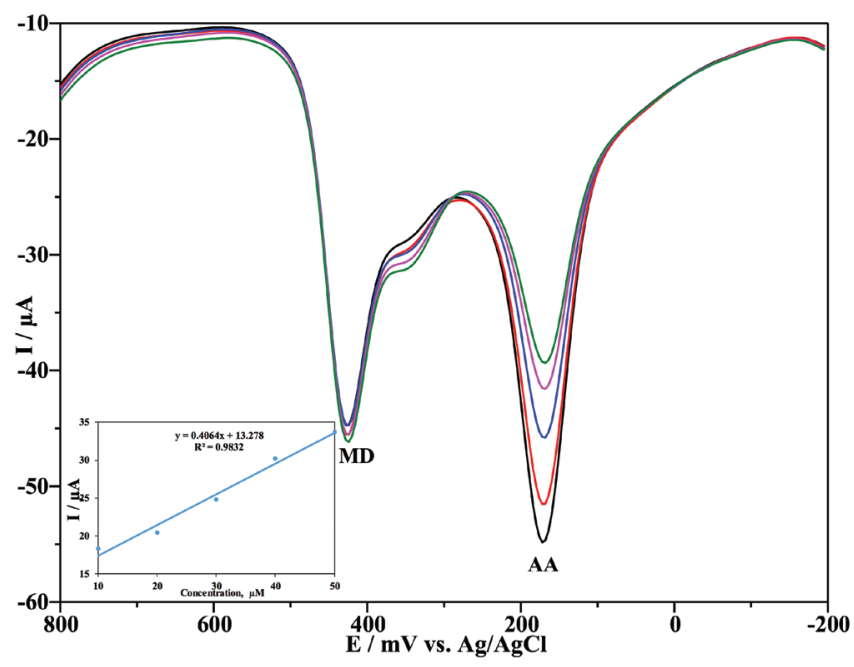

Figure 9. The increasing concentration of ascorbic acid $(0.1,0.2,0.3,0.4$, $0.5 \mathrm{mM}$ ) in the presence of $0.01 \mathrm{mM}$ methyldopa at poly ( $p$-aminobenzene sulfonic acid) in $0.1 \mathrm{M}$ phosphate buffer solution ( $\mathrm{pH} 3.0$ )

It is readily seen from Figure 8 that peak currents increase linearly with increasing MD concentration even in the presence of $A A$. In addition, the MD peak current was unaffected by the increasing AA concentration (Figure 9). Moreover, from the successive runs of the modified electrode in the binary mixture, it was observed that the voltammetric responses were almost invariable. The RSD for MD and 5 repeated measurements was less than $3 \%$. This reflects that the stability of the modified electrode was satisfactory.

\section{Analytical applications}

Five Alfamet tablets containing $250 \mathrm{mg}$ of MD in each tablet were directly weighed and powdered in a mortar. The calculated amount of MD corresponding to $100 \mathrm{mM}$ concentration stock solution was weighed and transferred to a $10-\mathrm{mL}$ volumetric flask and the volume was supplemented with ultrapure water. 
Table 2. Detection of methyldopa in commercial tablets

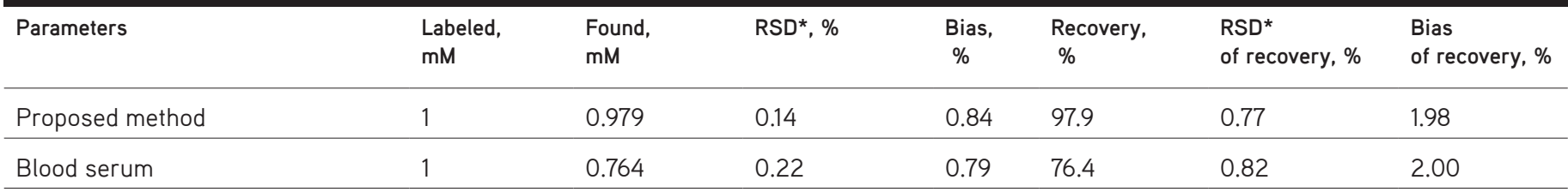

Each value is an average of five determinations.

${ }^{*} \mathrm{RSD}$ : Relative standard deviation

The contents of the flask were subjected to centrifugation at $5000 \mathrm{rpm}$ for $15 \mathrm{~min}$ to effect complete dissolution. The prepared mixture was filtered using paper filter and diluted using appropriate amounts of double distilled water. The serum samples were collected from a research hospital and were centrifuged (15 min at $5000 \mathrm{rpm}$ ) and then diluted 10 times with double distilled water without any additional pretreatment. Before the voltammetric determination, appropriate amounts of prepared real samples were added to $10 \mathrm{~mL}$ of phosphate buffer solution with optimum $\mathrm{pH}(\mathrm{pH}$ 3.0) and then transferred to the electrochemical cell for electrochemical measurements. The standard addition method was used to determine MD in the real and spiked samples.

The quantity of MD in the tablets was computed from the suitable calibration graphs. Furthermore, the accuracy of the proposed techniques was checked by carrying out recovery studies. Recovery results obtained from the calibration graph can be seen in Table 2. The proposed method was successfully performed on real samples in the presence of interferences.

\section{CONCLUSION}

A poly ( $p$-ABSA) modified electrode was applied for electrocatalytic assay of MD. The modified GCE indicated high electrocatalytic activity for MD. The modified GCE provides much sensitivity and selectivity in the assay of MD. Moreover, the modified electrode showed easy regeneration and good repeatability and stability. The modified GCE can be used under the selected conditions (in PBS, $\mathrm{pH}$ 3) for the determination of MD. The results show that the proposed method can be easily used in the determination of MD in drug samples and clinical analyses. It has been observed that this method can be used to identify MD in blood serum.

\section{ACKNOWLEDGEMENTS}

The Research Fund Unit of İnönü University financially supported this study (Grant no. APYB: 2010/30).

Conflict of Interest: No conflict of interest was declared by the authors.

\section{REFERENCES}

1. Hoffman BB, Lefkowitz RJ. In: Gilman AG, Hardman JG, Limbird LE, Molinoff PB, Ruddon RW, eds. The Pharmacological Basis of Therapeutics (9th ed). New York; McGraw-Hill; 1996:1908-1984.
2. Katzung EG, Masters SS, Trevor AJ. In: Katzung BG, ed. Basic and Clinical Pharmacology (12 ${ }^{\text {th }}$ ed). New York; McGraw-Hill; 2012:79-96.

3. Zecevic M, Zivanovic L, Agatonovic SK, Minic D. The use of a response surface methodology on HPLC analysis of methyldopa, amiloride and hydrochlorothiazide in tablets. J Pharm Biomed Anal. 2001;24:1019-1025.

4. Ballantine J, Woolfson AD. Determination of catecholamines in pharmaceutical preparations by differential pulse polarography at the glassy carbon electrode. Int J Pharmaceutics. 1979;3:239-246.

5. Badawy SS, Issa YM, Tag-Eldin AS. Potentiometric determination of L-dopa, carbidopa, methyldopa and aspartame using a new trinitrobenzenesulfonate selective electrode. Electroanalysis. 1996;8:1060-1064.

6. Wahbi AM, Abdine H, Korany M, Abdel-Hay MH. Sodium cobaltinitrite as a reagent for determining some phenolic drugs. J Ass Anal Chem. 1978;61:1113-1117.

7. Nagaraja P, Vasantha RA, Sunitha KR. A new sensitive and selective spectrophotometric method for the determination of catechol derivatives and its pharmaceutical preparations. J Pharm Biomed Anal. 2001;25:417-424.

8. Abdulrahman LK, Al-Abachi AM, Al-Qaissy MH. Flow injectionspectrophotometric determination of some catecholamine drugs in pharmaceutical preparations via oxidative coupling reaction with p-toluidine and sodium periodate. Anal Chim Acta. 2005;538:331335.

9. Levine M. New concepts in the biology and biochemistry of ascorbic acid. N Engl J Med. 1986;314:892-902.

10. Kajiya Y, Sugai H, Iwakura C, Yoneyama H. Glucose sensitivity of polypyrrole films containing immobilized glucose oxidase and hydroquinonesulfonate ions. Anal Chem. 1991;63:49-54.

11. Arrigan DWM, Lowens MJ. Polypyrrole films doped with an electroactive sulfonated chelating reagent: electrochemical characterization and the detection of metal ions. Electroanalysis. 1999;11:647-652.

12. Gholiv MB, Amiri M. Preparation of polypyrrole/nuclear fast red films on gold electrode and its application on the electrocatalytic determination of methyl-dopa and ascorbic acid. Electroanalysis. 2009;21:2461-2467.

13. Gao Z, Ivaska A. Electrochemical behaviour of dopamine and ascorbic acid at overoxidized polypyrrole(dodecyl sulphate) filmcoated electrodes. Anal Chim Acta. 1993;284:393-404.

14. Gao Z, Zi M, Chen B. Permeability controllable overoxidised polypyrrole film modified glassy carbon electrodes. Anal Chim Acta. 1994;286:213-218.

15. Saeed S, Reyhaneh-Sadat S, Zahra K. Sensitive electrochemical sensor for determination of methyldopa based on polypyrrole/ 
carbon nanoparticle composite thin film made by in situ electropolymerization. Electroanalysis. 2011;23:2248.

16. Behzad R, Neda A, Ali AE. Adsorptive stripping voltammetry determination of methyldopa on the surface of a carboxylated multiwall carbon nanotubes modified glassy carbon electrode in biological and pharmaceutical samples. Colloids and Surfaces B Biointerfaces. 2013;109:253-258.
17. Seyed ZM, Hadi B, Malihe J, Ali A. Nanomolar determination of methyldopa in the presence of large amounts of hydrochlorothiazide using a carbon paste electrode modified with graphene oxide nanosheets and 3-(4'-amino-3'-hydroxy-biphenyl-4-yl)-acrylic acid. Electroanalysis. 2015;27:2421-2430.

18. Diaz A, Bargon J, Handbook of Conducting Polymers, Skotheim, TA, ed, New York; Marcel Dekker Inc. 1986:1:81-82. 